E51

.1392

vol. 10

no. 5

NMAI

INDIAN NOTES

ND MONOGRAPHS

VOL. $\mathrm{X}$

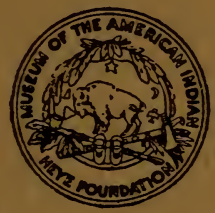

NO. 5

A SERIES OF PUBLICATIONS RELATING TO THE AMERICAN ABORIGINES

\title{
A BIRD-QUHL BELT OF THE SAUK AND FOX INDIANS
}

BY

M. R. HARRINGTON

\section{NEW YORK}

YOSEUM OF THE AMERICAN INDIAN

HEYE FOUNDATION

1920 
Publications of the Museum of the American Indian, Heye Foundation

THE GEORGE G. HEYE EXPEDITION CONTRIBUTIONS TO SOUTH AMERICAN ARCHAEOLOGY

Vol. 1

The Antiquities of Manabi, Ecuador: A Preliminary Report. By Marshall H. Saville. 1907. $\$ 25.00$.

Vol. 2

The Antiquities of Manabi, Ecuador: Final Report. By Marshall H. Saville. 1910. $\$ 25.00$.

CONTRIBUTIONS FROM THE MUSEUM OF THE AMERICAN INDIAN, HEYE FOUNDATION

Vol. 1

No. 1: Lucayan Artifacts from the Bahamas. By Theodoor de Booy. Reprinted from Amer. Anthropol., Vol. 15, 1913, No. 1. 50c.

No. 2: Precolumbian Decoration of the Teeth in Ecuador, with some Account of the Occurrence of the Custom in other parts of North and South America. By Marshall H. Saville. Reprinted from Amer. Anthropol., Vol. 15, 1913, No. 3. 50c.

No. 3: Certain Kitchen-middens in Jamaica. By Theodoor de Booy. Reprinted from Amer. Anthropol., Vol. 15, 1913, No. 3. (Reprinted, 1919.) 50c.

No. 4: Porto Rican Elbow-stones in the Heyc Museum, with discussion of similar objects, clsewhere. By J. Walter Fewkes. Reprinted from Amer Anihropol., Vol. 15, 1913, No. 3. $50 \mathrm{c}$. 


\section{INDIAN NOTES AND MONOGRAPHS}

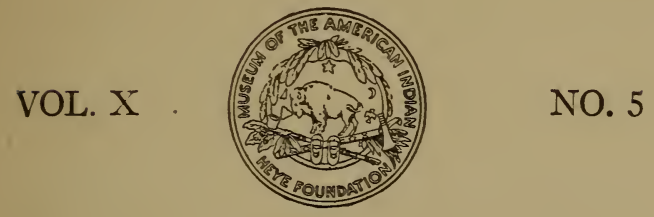

A SERIES OF PUBLICATIONS RELATING TO THE AMERICAN ABORIGINES

A BIRD-QUILL BELT OF THE SAUK AND FOX INDIANS

BY

M. R. HARRINGTON

NEW YORK

MUSEUM OF THE AMERICAN INDIAN

HEYE FOUNDATION

1920 
This series of Indian Notes ANd MonoGRAPHS is devoted primarily to the publication of the results of studies by members of the staff of the Museum of the American Indian, Heye Foundation, and is uniform with Hispanic Notes and MonografHs, published by the Hispanic Society of America, with which organization this Museum is in cordial coöperation. 


\title{
A BIRD-QUILL BELT OF THE SAUK AND FOX \\ INDIANS
}

\author{
BY \\ M. R. HARRINGTON
}






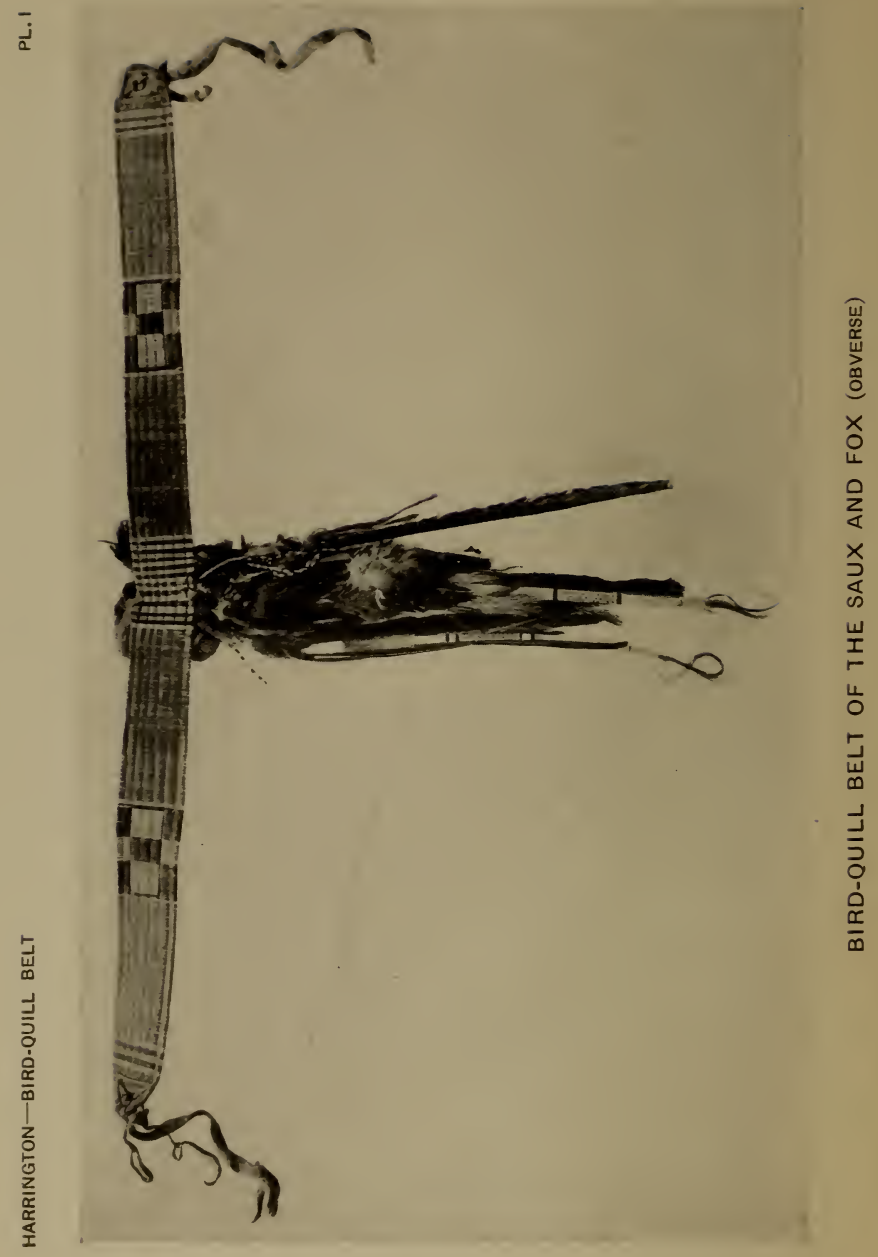




\begin{tabular}{|l}
\hline A BISD-QUILL BELT OF THE \\
BAUK AND FOX INDIANS \\
Bith its neat decoration in colored \\
bird-quills, is valuable to the col- \\
lections of the Museum of the \\
American Indian, Heye Foundation, not \\
only because it represents the period of \\
Indian art before the introduction of glass \\
beads by the whites, but also because ex- \\
amples of bird-quill decoration of any kind \\
are now rare. \\
The belt formed part of the contents of \\
a "war-bundle" collected from the Sauk \\
and Fox Indians of Oklahoma, and, be- \\
cause it was considered a powerful amulet \\
and to confer warlike powers on its wearer, \\
it was donned only on the warpath, after \\
the enemy had been sighted, and in the \\
ceremonies connected with the bundle. \\
\hline I N D I A N N O T E S
\end{tabular}




\begin{tabular}{|c|c|}
\hline 48 & SAUK AND FOX \\
\hline & $\begin{array}{l}\text { While the belt itself and the symbols on } \\
\text { it were considered powerful magically, much } \\
\text { of the power, according to Indian ideas, } \\
\text { resided in the bunch of feathers attached } \\
\text { to the back of the belt so as to hang down } \\
\text { behind the wearer like a tail. Of these, the } \\
\text { skin of a crow gave to the warrior the } \\
\text { watchful cunning of that bird, and the } \\
\text { hawk-feathers the hawk's power of swift } \\
\text { attack, while the red-dyed eagle-down sym- } \\
\text { bolized blood and war. Four little bundles } \\
\text { of herbs attached to the bunch had the } \\
\text { power, the Indians believed, to turn aside } \\
\text { arrows and bullets. } \\
\text { The belt itself is about } 1 \frac{3}{4} \text { inches wide } \\
\text { and } 29 \frac{1}{2} \text { inches long; it is made of buffalo- } \\
\text { hide, with loops at the ends and skin } \\
\text { strings to tie it about the body. The bird- } \\
\text { quill decoration completely covers the side } \\
\text { supposed to be worn outward, and consists } \\
\text { of a background of dark red, divided into } \\
\text { two fields by a transverse band of black } \\
\text { and white stripes in the middle, and finished } \\
\text { at each end with a similar though narrower } \\
\text { band of stripes. In the center of each red } \\
\text { field there is a black rectangle outlined in }\end{array}$ \\
\hline $\mathrm{X}$ & INDIAN NOTES \\
\hline
\end{tabular}





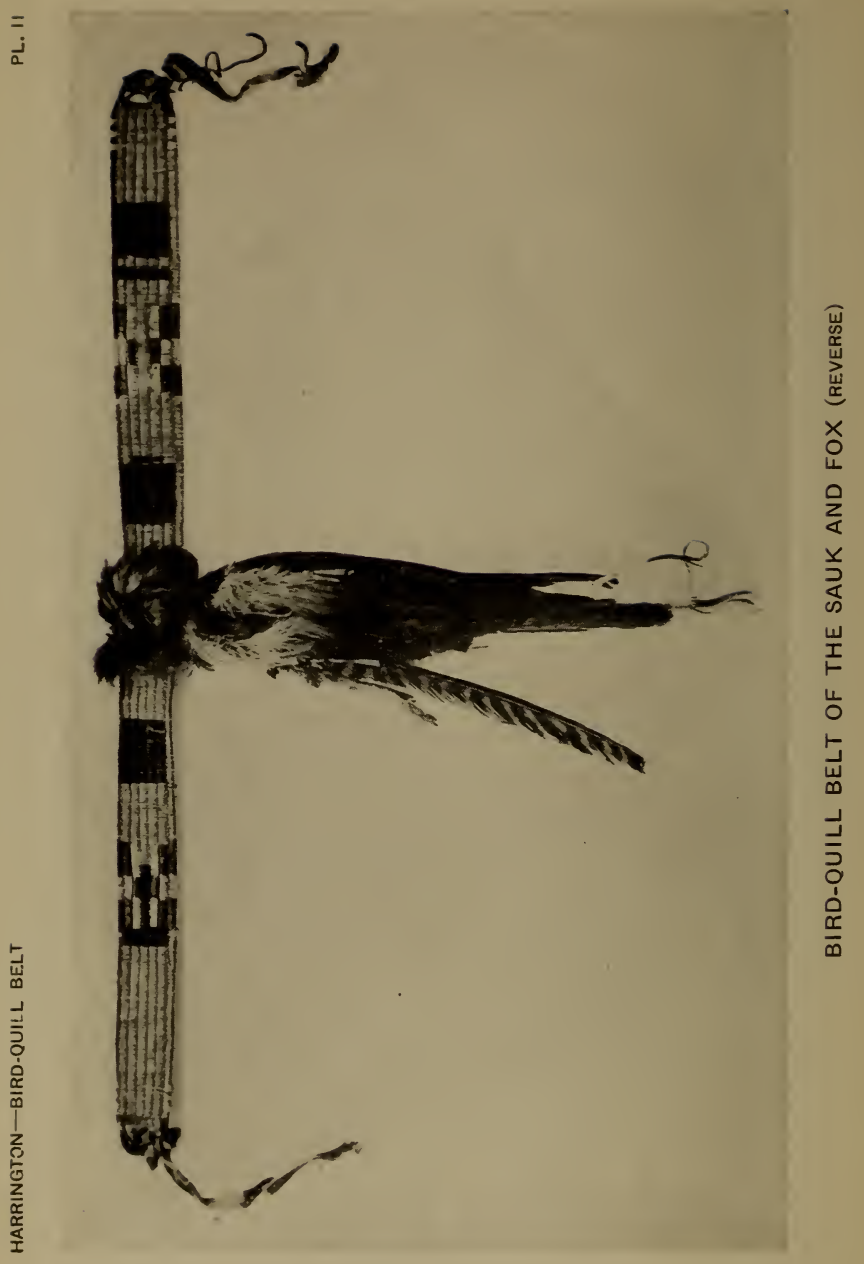




\section{B IR D-Q UILL B EL T}

white, and containing a white cruciform figure with a black, rectangular center. On the inner surface of the belt the decoration consists of alternate rectangles of black and yellow buffalo-wool yarn, and the crosses in bird-quills brought through from the front.

Both black and red quills have been colored with native dyes, the white ones left their natural color. Laid side by side transversely of the belt, they are held in place by six parallel lines of sinew stitching which penetrate the belt by means of longitudinal slits made for the purpose and engage the buffalo-wool yarn on the back, which is also laid transversely. The ends of the quills are carefully bent over the edges of the leather and neatly fastened under the yarn, presenting an attractive finish.

The belt and the bundle of which it forms a part have been mentioned in the writer's paper on the "Sacred Bundles of the Sac and Fox Indians,"1 and the use of birdquills in decoration by the Eskimo and others in Orchard's book on the subject. ${ }^{2}$

\section{A N D MONOGRAPHS}




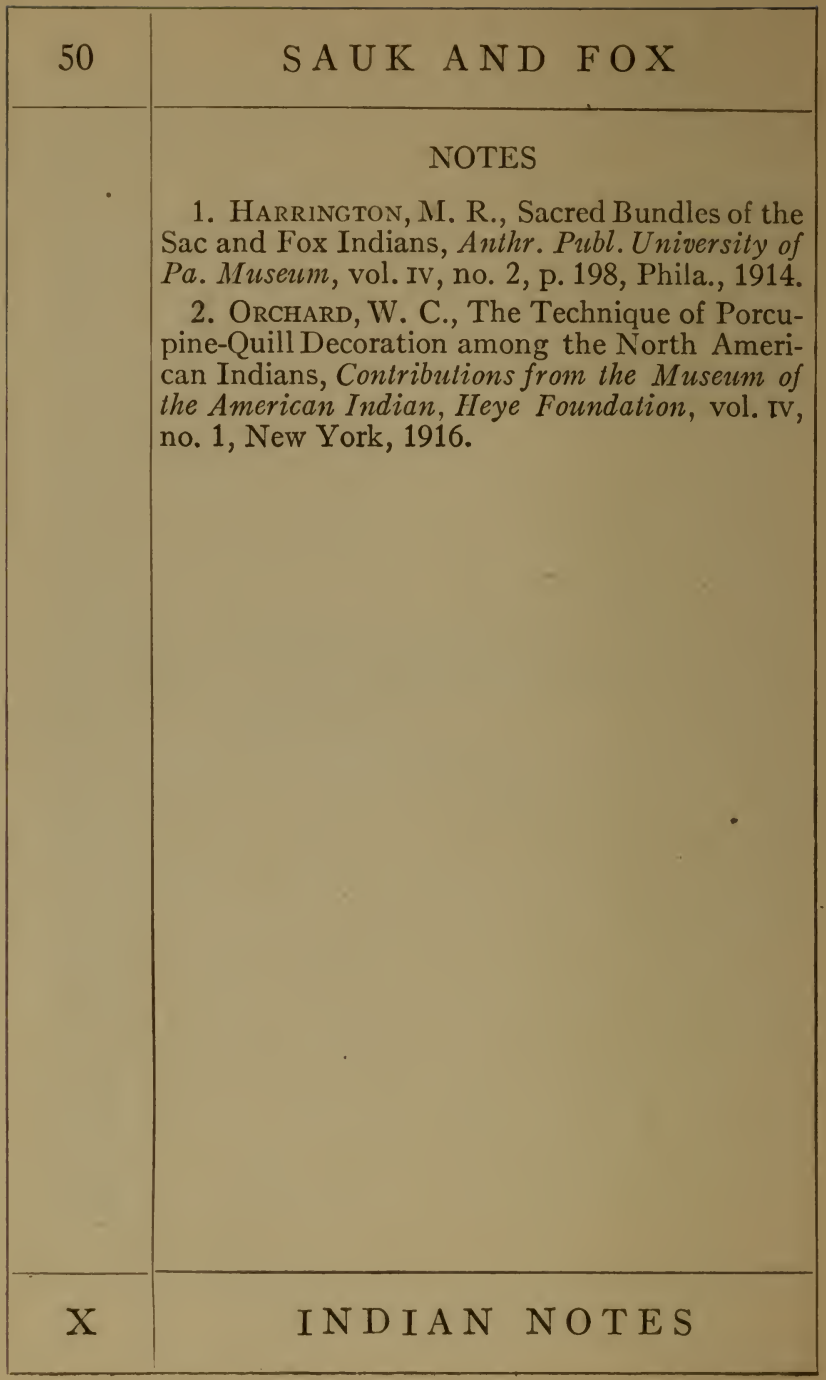


No. 5: Note on the Archaeology of Chiriqui. By George Grant MacCurdy. Reprinted from Amer. Anthropol., Vol. 15, 1913, No. 4. $50 \mathrm{c}$.

No. 6: Petroglyphs of Saint Vincent, British West Indies. By Thomas Huckerby. Reprinted from Amer. Anthropol., Vol. 16, 1914. No. 2. $50 \mathrm{c}$.

No. 7: Prehistoric Objects from a Shell-heap at Erin Bay, Trinidad. By J. Walter Fewkes. Reprinted from Amer. Anthropol., Vol. 16, 1914, No. 2. 50c.

No. 8: Relations of Aboriginal Culture and Environment in the Lesser Antilles. By J. Walter Fewkes. Reprinted from Bull. Amer. Geogr. Soc., Vol. 46, 1914, No. 9, 50c.

No. 9: Pottery from Certain Caves in Eastern Santo Domingo, West Indies. By Theodoor de Booy. Reprinted from Amer. Anthropol., Vol. 17, 1915, No. 1.50 c.

\section{Vol. 2}

No. 1: Exploration of a Munsee Cemetery near Montague, New Jersey. By George G. Heye and George H. Pepper. 1915. \$1.00.

No. 2: Engraved Celts from the Antilles. By J. Walter Fewkes. 1915. 50c.

No. 3: Certain West Indian Superstitions Pertaining to Celts. By Theodoor de Booy. Reprinted from Journ. Amer. Folk-Lore, Vol. 28, No. 107, 1915 . 50c.

No. 4: The Nanticoke Community of Delaware. By Frank G. Speck. 1915. \$1.00.

No. 5: Notes on the Archeology of Margarita Island, Venezuela. By Theodoor de Booy. 1916. 50c.

No. 6: Monolithic Axes and their Distribution in Ancient America. By Marshall H. Saville. 1916. 50c. 


\section{Vol. 3}

Physical Anthropology of the Lenape or Delawares, and of the Eastern Indians in General. By Aleš Hrdlicka. (Bur. of Amer. Ethnol., Bull. 62, 1916, with added title-page and cover.) $\$ 1.00$.

\section{Vol. 4}

No. 1: The Technique of Porcupine-Quill Decoration among the North American Indians. By William C. Orchard. 1916. $\$ 1.00$.

No. 2: Certain Archeological Investigations in Trinidad, British West Indies. By Theodoor de Booy. Reprinted from Amer. Anthropol., Vol. 19, 1917, No. 4. 50c.

No. 3: The Nacoochee Mound in Georgia. By George G. Heye, F. W. Hodge, and George H. Pepper. 1918. $\$ 1.50$.

\section{Vol. 5}

No. 1: A Letter of Pedro de Alvarado Relating to his Expedition to Ecuador [1534]. By Marshall H. Saville. 1917. 50c.

No. 2: The Diegueño Ceremony of the DeathImages. By E. H. Davis. $1919.50 \mathrm{c}$.

No. 3: Certain Mounds in Haywood County, North Carolina. By George G. Heye. Reprinted from Holmes Anniversary Volume, 1916. $1919.50 \mathrm{c}$.

No. 4: Exploration of Aboriginal Sites at Throgs Neck and Clasons Point, New York City. By Alanson Skinner. 1919. \$1.00.

Address:

MUSEUM OF THE AMERICAN InDIAN, Heye

FOUNDATION,

BROADWAY AT 155TH ST.,

NEW YORK CITY 